\title{
Intraspecific and interspecific variation in prickly poppy resistance to non-native generalist caterpillars
}

\author{
Jacob Suissa and Kasey E. Barton*
}

Botanical Sciences

96 (2): 168-179, 2018

DOI: 10.17129/botsci.1858

Received:

July 7th, 2017

Accepted:

August 23rd, 2017

Associated Editor:

Juan Núñez Farfán

\begin{abstract}
Background: Prickly poppies (genus Argemone, Papaveraceae) epitomize well-defended plants. With high prickle densities and exudation of bright yellow latex from glaucous leaves, there are few reports of herbivore damage on these plants. Yet, little ecological work has examined within-plant or among-species variation in levels of anti-herbivore defenses in prickly poppies.

Questions: Are prickly poppies well defended against generalist herbivores? Does chemical defense vary within prickly poppy plants in a pattern consistent with optimal defense theory?

Species study: Argemone glauca, A. mexicana, A. ochroleuca, A. platyceras were examined in bioassays using generalist caterpillars, Agrotis ipsilon Hufnagel and Chrysodeixis eriosoma Doubleday (Noctuidae).

Study sites and dates: Seeds were collected from field populations in Mexico (2015) and Hawaii (2011); experiment was conducted at the University of Hawaii at Manoa, Fall 2015.

Methods: Using a pair of no-choice bioassays, variation in the quality of whole-leaf and chemical extract infused artificial diets for caterpillar development was assessed.

Results: Survivorship was lowest on the control lettuce diet, and varied little between poppy diets although pupal mass was marginally lower for caterpillars reared on A. platyceras than A. ochroleuca. Isolating the effects of plant chemistry, C. eriosoma performance was most strongly reduced by seed extracts, with an extension in pupal development time by one week compared to herbivores reared on other diets, as well as a significant reduction in mean adult mass.

Conclusions: These results are consistent with optimal defense theory, reflecting greater allocation of defense in tissues of high fitness value (i.e., seeds). Future work with native herbivores, chemical analyses, and investigations into alternative functions for these plant traits would shed new light on this interesting group of plants.
\end{abstract}

Key words: latex, no-choice bioassay, plant defense, plant-herbivore interactions, prickles
Department of Botany, University of Hawai'i at Mānoa, Honolulu, USA.

*Corresponding author:

kbarton@hawaii.edu

This is an open access article distributed under the terms of the Creative Commons Attribution License CC BY-NC (4.0) international. 
erbivory is an important selective force acting on plant defense traits. The continuous arms-race has resulted in selection for a remarkable diversity of physical and chemical defenses in plants (Ehrlich \& Raven 1964, Fritz \& Simms 1992, Bennett \& Wallsgrove 1994, Hanley et al. 2007). Herbivores have in turn evolved means of detoxifying, avoiding, or tolerating plant defenses, giving rise to a diversity of herbivore feeding guilds and approaches (Karban \& Agrawal 2002). Most plant species express multiple defense traits (Koricheva et al. 2004), and in some cases, multiple traits may interact in their effects on herbivores, leading to synergies and evolving into defense syndromes (Agrawal \& Fishbein 2006). Knowing whether plants or herbivores are leading the coevolutionary arms race (in other words, is plant defense or herbivore offense dominating a particular interaction) is difficult to identify. Moreover, teasing apart the effects of defense traits that co-occur on herbivores can be challenging. To provide new insights into these unanswered questions, we have examined the combined and separate effects of two putative defense traits (latex and prickles) in a group of plants that appear to be leading the coevolutionary arms race against herbivores, the prickly poppies (genus Argemone, Papaveraceae; Figure 1).

The prickly poppies appear to epitomize well-defended plants. Vegetative tissues and fruits are covered with sharp, non-vascularized prickles, with high densities found on leaf edges, flowering stalks and capsules. Although spinescence is generally thought to be particularly deterrent to mammalian herbivores (Potter \& Kimerer 1988, Hanley et al. 2007), prickles may also deter insect herbivores (Grubb 1992, Briand \& Soros 2001). Prickly poppies also have tough leaves with a thick and waxy cuticle, giving them a glaucous appearance. Although the epicuticular waxes in glaucous leaves confer an ecophysiological advantage in arid environments (Schreiber \& Riederer 1996, Oliveira et al. 2003, Agrawal et al. 2009), such as those where prickly plants are common, glaucous leaves have also been found to reduce insect herbivory (Eigenbrode \& Espelie 1995, Agrawal et al. 2009, Scholz et al. 2010).

In addition to these potential physical defenses, prickly poppies also appear to be chemically defended as plants exude a bright yellow or orange latex upon shoot damage (Barton 2014, Hoan et al. 2014). In the only species that has been well studied, Argemone mexicana, alkaloids in the protoberberine and protopine classes concentrate in the latex (Singh et al. 2010, Brahmachari et al. 2013). Extracts of A. mexicana leaves are broadly toxic, with detrimental effects reported for snails (Meléndez \& Capriles 2002), bacteria, fungi (Osho \& Adetunji 2010), dipteran larvae (Sakthivadivel \& Thilagavathy 2003), mice (Ansari et al. 2004), nematodes (Shaukat et al. 2002), and neighboring tomato plants (Shaukat et al. 2002). Humans who accidentally consumed A. mexicana seeds became ill and, in some cases, died (Verma et al. 2001). A recent study has also reported antibacterial activity for a second species of Argemone, A. ochroleuca (Reyes et al. 2011). Interestingly, latex and seed extracts from prickly poppies have been used medicinally for many years, providing further evidence for the bioactivity of prickly poppy tissues (Chang et al. 2003, Brahmachari et al. 2013).

Considering the well-supported roles for prickles, tough leaves, and latex in defense against herbivores (Hanley et al. 2007, Agrawal \& Konno 2009), it is likely that prickly poppies are well-defended plants. However, surprisingly little ecological research has focused on prickly poppies; thus plant-herbivore interactions involving Argemone species are not well characterized. Only one study has reported natural damage to Argemone plants in the field, showing that insect herbivory was scarce on A. corymbosa and A. munita in California (Goeden \& Ricker 1985). While low rates of defoliation were similarly observed on several species (A. mexicana, A. platyceras, and A. ochroleuca) during field surveys in Mexico, beetle herbivory on flowers was common (Kasey E. Barton \& Karina Boege, unpublished data). To our knowledge, no previous study has attempted to test the efficacy of prickly poppy defense traits on herbivores in a controlled context. The goal of this study is to test, for the first time, how effective the putative defense traits of prickly poppies are against insect herbivores. Because specialist herbivores are

\section{Author Contributions:}

KEB developed the conceptual framework; JS collected the data; JS and KEB analyzed data and contributed equally to the writing and revising of the manuscript. likely to have evolved feeding behaviors and detoxification pathways to minimize their susceptibility to resistance traits of their host plants (Ali \& Agrawal 2012), we focused on generalist leaf-feeding herbivores. Using a controlled lab approach of no-choice bioassays, we tested the performance of two generalist Lepidopteran species, (Agrotis ipsilon and Chrysodeixis eriosoma, Noctuidae), when fed whole-leaf or latex-infused artificial diets from four species of Argemone (Table 1). Measuring multiple aspects of herbivore performance, (mortality, time 
Figure 1. Photo of Argemone platyceras taken in Oaxaca, Mexico in May 2015 by KEB. Glaucous leaves and prickles are clearly visible. Latex exudes from any damaged shoot tissue, including both vegetative and reproductive structures.

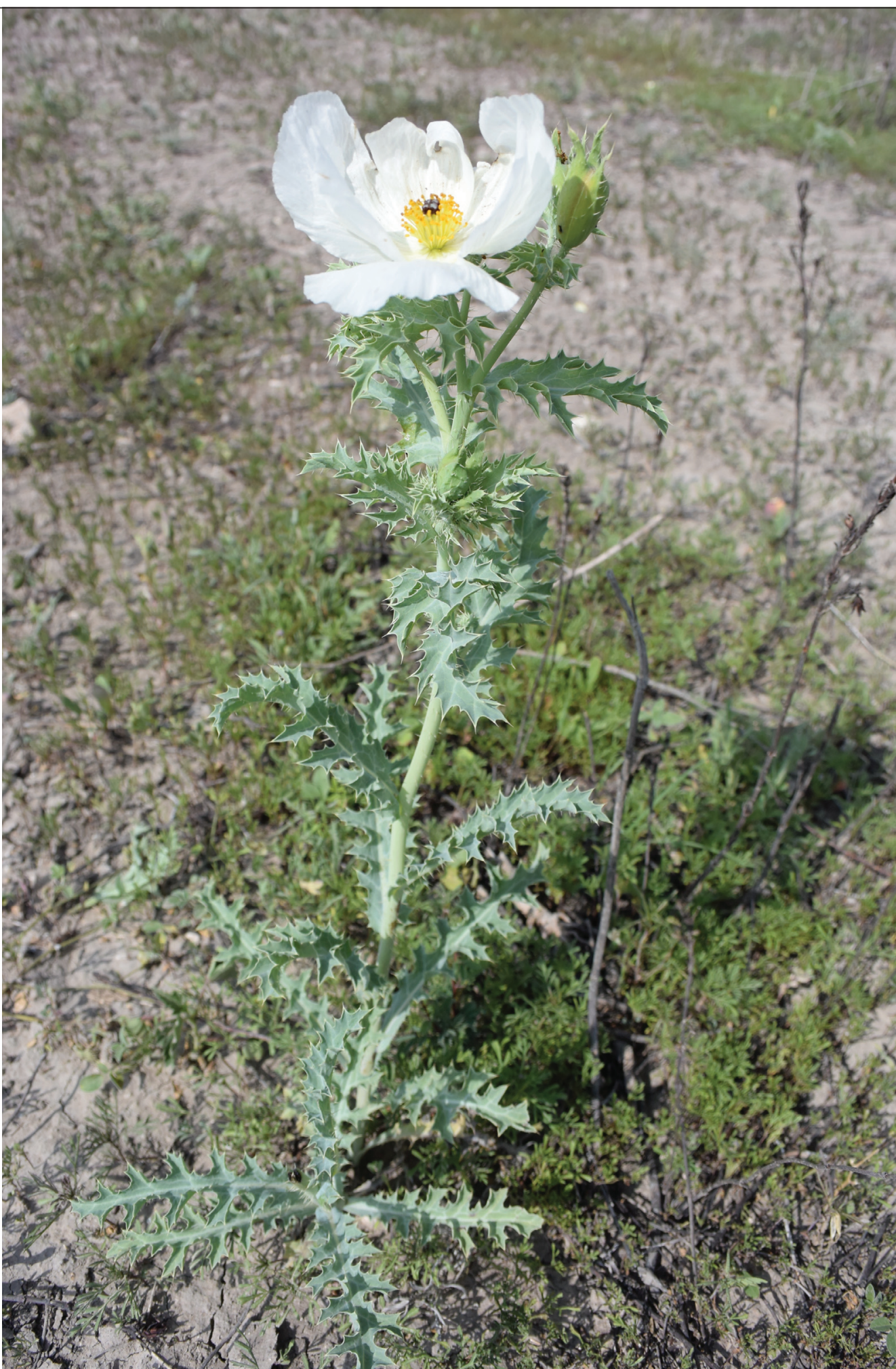

to pupation, pupal and adult mass, and time to emergence), we have a comprehensive measure of herbivore fitness (Kariyat \& Portman 2016). Because chemical metabolite concentrations tend to vary within plants consistent with the fitness value and likelihood of attack of tissues, as predicted by the Optimal Defense Theory (McCall \& Fordyce 2010), we also tested whether chemical extracts from leaves, roots, and seeds differed in their effects on caterpillar fitness. Damage to seeds are likely to have the greatest fitness consequences, and are likely to be tar- 
geted by herbivores, leading us to predict that defense should be prioritized to seeds, followed by leaves, and then roots.

In particular, we addressed the following two questions: i) Are prickly poppies well defended physically and chemically against generalist herbivores, as evidenced by a reduction in caterpillar performance? ii) Does chemical defense vary within prickly poppy plants in a pattern consistent with optimal defense theory (greater negative effect on caterpillar performance of diet containing chemical extracts from seeds $>$ leaves $>$ roots), and among species?

\section{Materials and methods}

Study System. Argemone (Papaveraceae) includes approximately 35 species native to the arid regions of the Americas (Schwarzbach \& Kadereit 1999). Many of these species, including $A$. mexicana L. and A. glauca Pope, have been used in traditional medicine (Capasso et al. 1997, Guizar-Gonzalez et al. 2012, Brahmachari et al. 2013). Prickly poppies are generally erect herbaceous annuals or short-lived perennials. This study includes four species of Argemone (Table 1). The Mexican poppy, A. mexicana, is native to Mexico, but has migrated worldwide to

\begin{tabular}{|c|c|c|c|c|}
\hline Species & Experiment & Native Range and Habitat Type & $\begin{array}{l}\text { Collection Site } \\
\text { and Date }\end{array}$ & $\begin{array}{l}\text { Mean Leaf Prickle } \\
\text { Density }\left(\mathrm{cm}^{-2}\right)\end{array}$ \\
\hline A. glauca & Extract (seeds) & $\begin{array}{l}\text { Hawaii; dry uplands and coastal } \\
\text { habitats }\end{array}$ & $\begin{array}{l}\text { US, Hawaii, } \\
\text { Hawaii Is. } 2011\end{array}$ & $15.0 \pm 2.3(n=9)$ \\
\hline A. mexicana & $\begin{array}{l}\text { Extract (seeds, } \\
\text { leaves, roots) }\end{array}$ & $\begin{array}{l}\text { Mexico; disturbed habitats, hot } \\
\text { climates; worldwide weed }\end{array}$ & $\begin{array}{l}\text { US, Hawaii, Maui } \\
\text { and Hawaii Is. } \\
\text { 2011, } 2015\end{array}$ & $2.6 \pm 0.6(n=7)$ \\
\hline A. ochroleuca & $\begin{array}{l}\text { Whole-leaf; } \\
\text { Extract (seeds) }\end{array}$ & $\begin{array}{l}\text { Mexico; disturbed roadsides and } \\
\text { near agricultural fields }\end{array}$ & $\begin{array}{l}\text { Mexico, Guanajuato } \\
2015\end{array}$ & $1.8 \pm 0.5(n=4)$ \\
\hline A. platyceras & $\begin{array}{l}\text { Whole-leaf; } \\
\text { Extract (seeds, } \\
\text { leaves, roots) }\end{array}$ & $\begin{array}{l}\text { Mexico; mid- and high- elevation } \\
\text { pastures and near agricultural } \\
\text { fields }\end{array}$ & $\begin{array}{l}\text { Mexico, Oaxaca } \\
2015\end{array}$ & $1.6 \pm 0.7(n=5)$ \\
\hline
\end{tabular}

become a pandemic weed. Two additional species common in Mexico were included, A. platyceras Link \& Otto and A. ochroleuca Sweet. The fourth species is the Hawaiian endemic, $A$. glauca ("pua kala"), which is found on all the main islands, particularly in dry coastal habitats and high elevations (Wagner et al. 1999). Coleoptera and domestic ungulates are thought to be the primary herbivores of continental species of Argemone (Barton \& Boege, unpublished data), and due to the large-scale extinction of native Hawaiian herbivores, it is unknown what historically fed on pua kala, although likely herbivores would have been insects, flightless ducks, and land crabs (Givnish et al. 1994, James \& Burney 1997).

Plants used in the bioassays were grown from seeds collected in Hawaii for both A. mexicana and A. glauca in 2011 and 2015, and from seeds collected in Mexico in May 2015 for A. ochroleuca (Guanajuato state) and A. platyceras (Oaxaca state). Seeds were removed from capsules and stored dry in the lab until sowing in Fall 2015. After germination, seedlings were transplanted into 1-gallon pots filled with equal parts Promix BX (65-75 \% Canadian sphagnum peat moss, perlite, dolomitic and calcitic limestone, macro- and micronutrients, and a mycorrhizae inoculum) and black cinder and moved into a greenhouse with daily watering.

Two different generalist Noctuid Lepidoptera species were used in no-choice bioassays, based on availability at the time plants were ready for the bioassays. For the whole-leaf bioassay, the black cutworm, Agrotis ipsilon was used; for the chemical extract bioassay, Chrysodeixis eriosoma was used. Agrotis ipsilon is a widespread agricultural pest found worldwide, including on many islands, which feeds on a diversity of agricultural crops from at least 18 plant families (Liu et al. 2016). A. ipsilon caterpillars used in this study were reared from eggs laid on paper towels from moths captured from the vicinity of agricultural fields in Hilo, Hawaii 
Island in September 2015. Chrysodeixis eriosoma is also a pandemic noctuid that feeds on many agriculturally important plants such as brassicas, corn, and tomato (Luther et al. 1996). C. eriosoma caterpillars were reared from eggs laid from moths collected near agricultural fields in Waimanalo, Oahu Island in October 2015.

Whole Leaf Bioassay. This experiment tested the performance of $A$. ipsilon caterpillars reared on a whole-leaf diet of two species of prickly poppies, A. platyceras and A. ochroleuca. These species have similar prickle densities (Table 1), so any difference in caterpillar performance fed on these diets would most likely be driven by differences in the leaf chemistry or leaf toughness. A third group of caterpillars (the control treatment group) were reared on a diet of store-bought organic lettuce (a mixture of green-leaf and romaine lettuces) that was thoroughly washed to remove any potential contaminants prior to use. Because caterpillars were too small to move immediately following hatching, all of them were fed on a mixed diet of lettuce and Amaranthus spp. leaves (collected near the St John Plant Laboratory on the UH-Manoa campus) for their first three days. After this period, caterpillars were moved to individual $2 \mathrm{oz}$ cups and randomly assigned to an experimental diet (A. platyceras, A. ochroleuca, or lettuce). After the fourth instar, they were moved to $10 \mathrm{oz}$ plastic containers. Leaves were collected from the greenhouse-grown poppy plants or from organic lettuce purchased from the grocery store, and new leaves were provided every 2 - 3 days as needed. The amount of leaf tissue provided to the larvae increased throughout instars. The total sample size was $\mathrm{N}=72$ caterpillars (10 replicates for each of the A. platyceras and A. ochroleuca diets and 52 replicates for the control diet).

Herbivore performance was measured in three ways: as percent survival in the larval stage, days to pupation, and pupal mass. At each feeding time, dead caterpillars were recorded to calculate $\%$ survival for each treatment group. As the larvae initiated pupation, these dates were recorded and analyzed as days to pupation, with day 0 being the start of the bioassay (approximately three days after hatching). The pupae were weighed when the chrysalises were fully melanized, yielding pupal mass. We interpret plant defense to be revealed by negative effects of the prickly poppy leaf diets compared to lettuce, expressed as lower percent survival, longer development period before pupation, and lower pupal mass.

Plant Extract Bioassay. To isolate the effects of chemical defense of prickly poppies, we conducted a second experiment using plant extracts incorporated into artificial diet, which was then fed to caterpillars of $C$. eriosoma. This experiment removes the potential defensive role of leaf sclerophylly and prickles to focus specifically on chemical defenses and their variation within plants (among organs) and among species. Following hatching, all caterpillars were immediately moved into $2 \mathrm{oz}$. containers with moist filter paper and were initially fed on a control artificial diet with no added plant extracts (General Purpose Lepidoptera diet from Frontier Agricultural Sciences containing wheat germ, soy flour base prepared with water and agar according to the diet instructions). At the 4 th instar, caterpillars were moved to larger containers $(20 \mathrm{oz}$.).

After six days on the control diet, caterpillars were randomly assigned to nine treatment diets which included the artificial diet prepared as for the control with the addition of $22 \mathrm{~mL}$ of aqueous plant extracts made from: Argemone glauca seeds; A. ochroleuca seeds; A. mexicana seeds; A. mexicana roots; A. mexicana leaves; A. platyceras seeds; A. platyceras roots; A. platyceras leaves; control diet with no added plant extract. The seed extracts were made from $800 \mathrm{mg}$ of seeds ground by mortar and pestle and then soaked in $22 \mathrm{~mL}$ distilled water for one hour. Leaf extracts were made from leaves cut along the midrib and lateral veins to release latex and soaked in $22 \mathrm{~mL}$ distilled water for one hour; a total of $161.5 \mathrm{~cm}$ length of leaves were used per species. Root extracts were made by soaking $25-30 \mathrm{~cm}$ of freshly excavated roots that were macerated and soaked for one hour in $22 \mathrm{~mL}$ distilled water. These extracts were then respectively decanted carefully to exclude all particulate matter into two artificial feed solutions, and allowed to cool and solidify in Petri dishes. Prepared diets were stored in the refrigerator, and new diet was prepared four times throughout the experiment to ensure caterpillars were fed fresh diet. Tissues from five plants were included for the root and leaf preparations so that plant extracts 
represented samples from a mixed genetic pool. Each treatment diet had 8-10 replicates, giving a total sample size of $\mathrm{N}=78$ caterpillars.

Herbivore performance was measured with five metrics in this experiment, including percent survival, days to pupation, pupal mass, days to eclosion, and adult moth mass. Mortality throughout the juvenile life stages (caterpillar and pupal) was recorded and analyzed as percent survival. Pupae were kept in their individual dishes until eclosion date, which was recorded and used to calculate the number of days from the onset of pupation through eclosion (days to eclosion). Adult moths were weighed as soon as the wings were fully dried. Including fitness metrics for all herbivore life stages gives us a more complete view of the potential negative effects of treatment diets, which might be missed by focusing only on the caterpillar stage (Kariyat \& Portman 2016).

Statistical Analyses. Data were analyzed using SAS for Windows version 9.2 (SAS Institute, Cary, NC). Percent survival was analyzed using the Fisher's exact test for the whole-leaf bioassay and a chi-square test for the plant extract bioassay. Continuous herbivore performance metrics included days to pupation, pupal mass, days to eclosion, and moth mass. For each experiment, the metrics were analyzed both separately and together with a multivariate analysis of variance. The MANOVA's tested whether diet (either whole-leaf or extracts incorporated into artificial diet) influenced herbivore performance. Because the MANOVA's revealed significant effects of diet (see Results), performance metrics were then analyzed separately with univariate ANOVA's. Pupal and adult mass were log-transformed to meet assumptions of homoscedasticity and normality.

\section{Results}

Whole Leaf Bioassay. Diet strongly affected Agrotis ipsilon caterpillar survival (Fisher's exact test $P<0.0001$ ). In sharp contrast to our prediction, caterpillars on the control lettuce diet had very high mortality (96\%) while all caterpillars reared on Argemone platyceras and A. ochroleuca leaves survived. For surviving caterpillars, diet significantly affected herbivore performance as revealed by the MANOVA (Wilks' $\lambda F_{4.36}=4.77, P=0.0034$ ). The univariate analyses reveal that both days to pupation $\left(F_{2,19}=3.47, P=0.0518\right)$ and pupal mass $\left(F_{2,19}=3.47, P=\right.$ 0.0520 ) were marginally significantly affected by diet. However, again in contrast with our predictions, caterpillars took longer to pupate and were smaller when reared on the control lettuce diet than on the prickly poppy leaves (Figure 2). For the 2 poppy species, A. ochroleuca was slightly better for herbivore development than A. platyceras, as evidenced by fewer days to pupation and larger pupal mass (Figure 2).

Plant Extract Bioassay. Chrysodeixis eriosoma caterpillar survival rates were consistently high across plant extract diets $\left(\chi^{2}=7.41\right.$, d.f. $\left.=8, P=0.494\right)$. As with the first experiment, the MANOVA indicated that diet significantly influenced the other metrics of herbivore performance (Wilks' $\lambda F_{32,190}=3.01, P<0.0001$ ). The univariate analyses revealed that a significant effect of diet on days to pupation $\left(F_{8,61}=6.02, P<0.0001\right)$ and a marginally significant effect of diet on adult mass $\left(F_{8,61}=2.01, P=0.0622\right)$ were driving this significant result. Days to pupation varied from a mean of 21 days for caterpillars reared on the control diet to 30 days for those reared on diet incorporating seed extracts of Argemone ochroleuca. In general, diets including seed extracts led to the slowest development rates while caterpillars reared on diets including extracts of poppy leaves and roots were similar to that of control diets; this pattern was consistent for both species for which extracts were taken from roots, leaves, and seeds (Argemone mexicana and A. platyceras; Figure 3a). There were no detectable effects of diet on pupal mass $\left(F_{8,61}=0.89, P=0.5307\right.$; Figure $\left.3 \mathrm{~b}\right)$ or the length of time it took for pupae to eclose $\left(F_{8,61}=1.26, P=0.2836\right.$; Figure $\left.3 \mathrm{c}\right)$. Although mean adult mass was marginally significantly influenced by diet, the magnitude of differences among treatment diets was small (Figure 3d) and unlikely to be biologically meaningful. Nonetheless, moths reared on control and leaf extract diets were slightly larger than moths reared on diets incorporating extracts of roots and seeds (Figure 3d). 
Figure 2. Effects of wholeleaf diet on (a) pupal mass and (b) days to pupation in Agrotis ipsilon herbivores. Error bars are \pm 1 s.e.
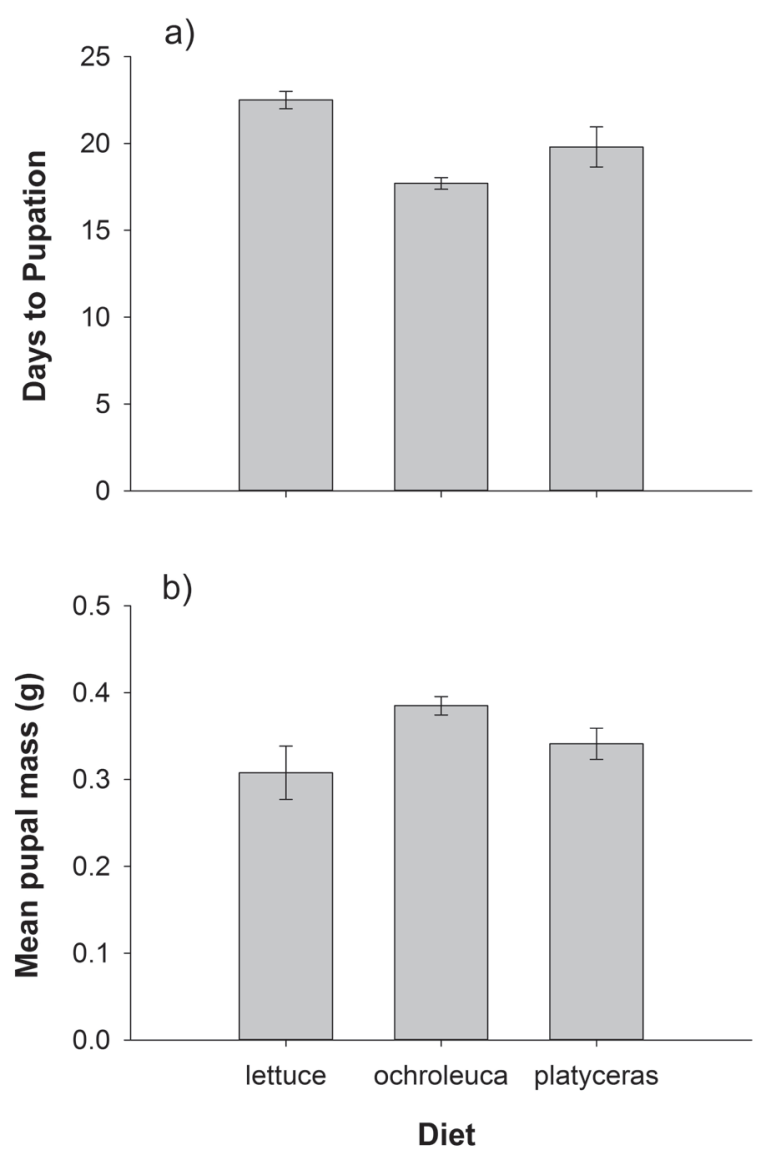

Figure 3. Effects of treatment diets on the fitness metrics of Chrysodeixis eriosoma herbivores, including: (a) days to pupation, (b) mean pupal mass, (c) days to eclosion, and (d) mean adult moth mass. Diets were prepared as artificial diet alone (C), or prepared with aqueous plant extracts of seeds, leaves, or roots from four species of Argemone: leaves of $A$. mexicana (ML) and $A$. platyceras (PL); roots of $A$. mexicana (MR) and $P$. platyceras (PR), seeds of $A$. mexicana (MS), A. platyceras (PS), A. ochroleuca (OS), and A. glauca (GS). Error bars are \pm 1 s.e.
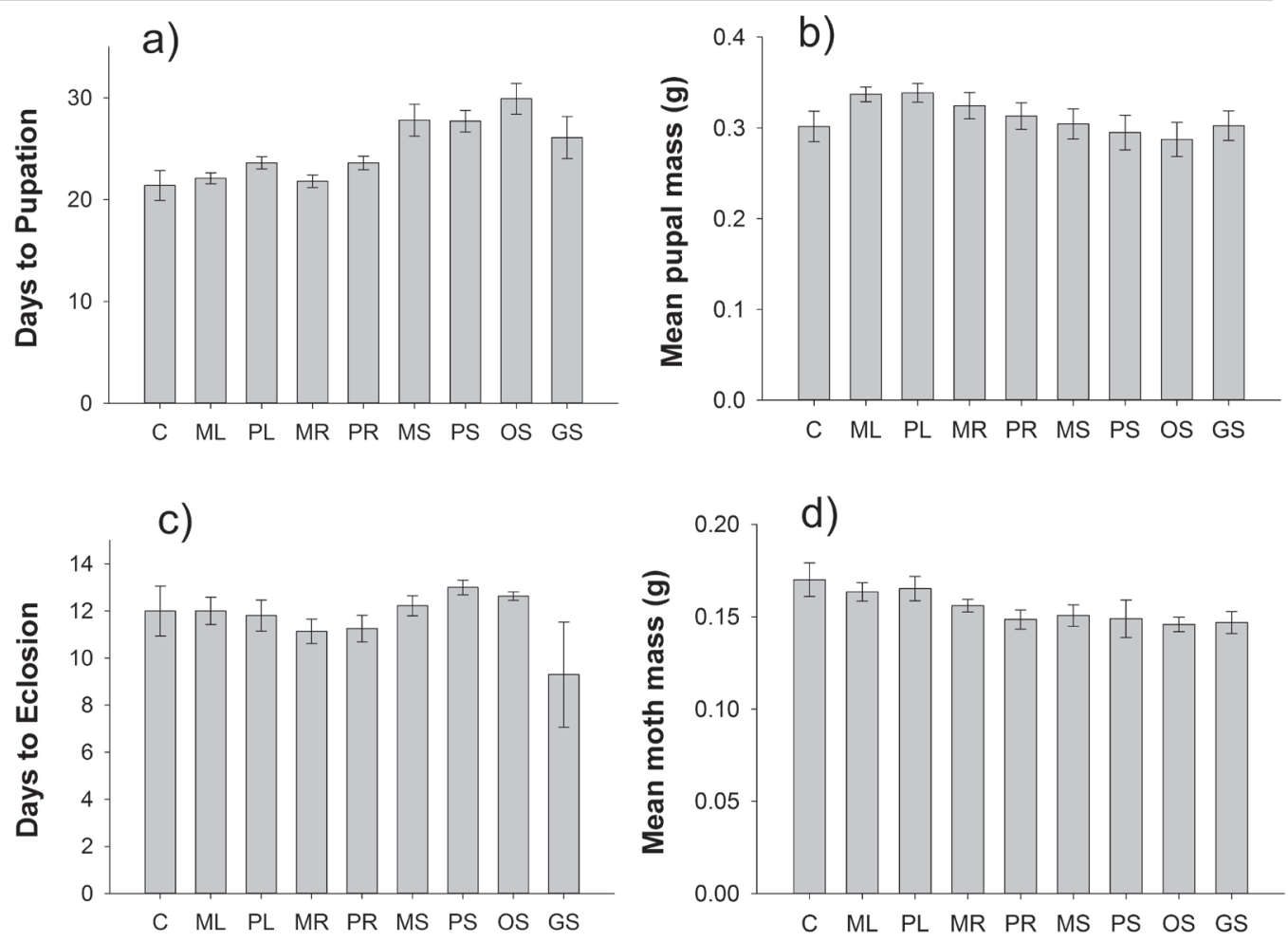

Diet
Diet 


\section{Discussion}

Prickly poppies appear to epitomize a plant that is leading the coevolutionary arms race with herbivores. Prickly poppies are covered with sharp prickles over all vegetative and most reproductive tissues; they exude a brightly colored and most certainly toxic latex; and their leaves are thick and tough. Yet, in a pair of bioassays, we found that the negative effects on generalist noctuid caterpillar performance were of relatively small magnitude, calling into question the importance of these traits for insect resistance. On the one hand, these results are consistent with a recent meta-analysis conducted by Smilanich et al. (2016), indicating that contrary to wideheld predictions, generalist herbivores do not generally suffer from reduced performance when fed diets with plant secondary compounds. On the other hand, our results may reflect more that prickly poppy defenses do not target insect herbivores, but rather, are specific to native herbivores and/or other guilds of herbivores such as vertebrate browsers. Because ecological research is lacking for the species examined here, we do not know the native guilds of herbivores which feed on prickly poppies. Moreover, it is possible that prickles provide resistance to fungal pathogens by preventing fungal spores from reaching the leaf surface. Clearly, additional research documenting natural patterns of herbivory and fungal pathogen infection would elucidate potential effects of latex and prickles on native poppy natural enemies.

Because of our paired bioassay approach, we can attempt to separate the effects of physical and chemical defenses in prickly poppies. The whole-leaf bioassay exposes herbivores to both physical and chemical resistance traits, although excised leaves may not contain as much latex as attached leaves. Caterpillars were reared on leaves of either Argemone ochroleuca or A. platyceras, two Mexican species with remarkably similar prickle densities (Table 1). Surprisingly, Agrotis ipsilon caterpillars performed relatively well on both species, and in contrast, suffered almost $100 \%$ mortality on the control diet of store-bought leaf lettuce. Because A. ipsilon is a common agricultural pest (Liu et al. 2016), we expected high performance on the lettuce diet. To reduce the likelihood that lettuce would include pesticides or other chemicals that would affect caterpillar development, we purchased organic lettuce and washed it thoroughly before offering it to caterpillars. Thus, while it is unlikely that the control diet unintentionally included deterrents, it is impossible to rule this out. Variation in nutrient levels of lettuce vs. prickly poppy leaves may also have contributed to these results, particularly if store-bought lettuce was nutrient-leached due to pre-sale storage practices (Konstantopoulou et al. 2010).

While it is difficult to ascertain the role of poppy chemistry (nutrients and secondary compounds in latex) in the whole-leaf bioassays, caterpillars seemed able to overcome the prickles. We observed larvae littering their containers with excised prickles, revealing behavioral traits enabling these caterpillars to feed on prickly plants without ingesting the prickles. These results are thus consistent with previous studies suggesting that spinescence targets mammalian rather than insect herbivores (Potter \& Kimmerer 1988, Hanley et al. 2007). However, it is feasible that this behavioral tactic was costly and/or other traits of the prickly poppy leaves were detrimental to Agrotis ipsilon development, as the pupal masses recorded in this study were approximately $60 \%$ smaller than has been reported in other studies on A. ipsilon (Saeki \& Crowley 2012, Xu et al. 2016).

In our second bioassay, we isolated plant chemistry to assess whether prickly poppies contain toxic secondary compounds that reduce herbivore performance. Previous work on Argemone mexicana has clearly revealed that the alkaloids in seeds and latex are toxic to a variety of organisms, including snails (Meléndez \& Capriles 2002), bacteria, fungi (Osho \& Adetunji 2010), dipteran larvae (Sakthivadivel \& Thilagavathy 2003), mice (Ansari et al. 2004), nematodes (Shaukat et al. 2002), neighboring tomato plants (Shaukat et al. 2002), and humans (Verma et al. 2001). Although the latex composition has not been studied in our other Argemone species, the consistent bright yellow/orange color led us to predict that artificial diets incorporating any Argemone extracts would reduce caterpillar performance compared to artificial diet alone. Surprisingly, Chrysodeixis eriosoma caterpillars developed well on all treatment diets including root and leaf extracts. In contrast, diets incorporating seed extracts extended the larval period, (longer pupation time) and led to smaller adult moths.

Because longer larval periods associated with susceptibility to predation and parasitism 
(Singer et al.2012), and developing into smaller moths, which are likely to have reduced reproductive potential (Honek 1993), these results suggest that these Argemone species defend seeds more than vegetative tissues such as roots and leaves. Higher toxicity for seeds compared to leaves and roots is consistent with our predictions based on the optimal defense theory, which posits that plants defend tissues relative to their fitness values and likelihoods of attack (McKey 1979). While numerous studies have compared chemical defense with respect to the ODT with general support for greater defense in young $v s$. old leaves, there is no detectable trend among studies comparing chemical defense in flowers vs. leaves (McCall \& Fordyce 2010). However, while comparisons of intra-plant variation in the secondary chemistry of seeds, roots, and leaves are relatively rare (most likely because different guilds of herbivores consume these different plant organs), there are many reports of chemically well defended seeds (Huang et al. 2011, Fricke et al. 2016). Additional chemical and ecological research is needed to confirm differences in secondary chemistry among plant tissues in these Argemone species and to examine how these intra-plant patterns relate to levels of herbivory in natural populations. Research on seed granivory would be particularly enlightening as to the role of secondary compounds in prickly poppy seeds.

Examination of the various fitness parameters examined for Agrostis ipsilon and Chrysodeixis eriosoma reveal interesting differences in how the prickly poppy diets influence herbivore development. In general, survival rates were high on treatment diets (excluding the very high mortality on lettuce), indicating that these caterpillars are able to successfully reach pupation on a diet of prickly poppy leaves or artificial diet incorporating prickly poppy extracts. The fitness trait most strongly influenced by treatment diets was the days to pupation, which differed significantly between whole leaf diets of Argemone ochroleuca vs. A. platyceras, and differed significantly among extract-infused artificial diets. In particular, C. eriosoma caterpillars reared on artificial diet incorporating seed extracts took about a week longer to pupate than caterpillars reared on artificial diet alone. According to the slow-growth-high-mortality hypothesis, herbivores that spend more time in the larval stage experience higher rates of parasitism and predation (Clancy \& Price 1987, Benrey \& Denno 1997). Thus, although we would not expect C. eriosoma caterpillars to eat prickly poppy seeds under natural contexts, this response is consistent with the presence of secondary compounds that reduce performance of the herbivores. Remarkably, mean number of days in the pupal stage ("days to eclosion") and mean adult moth mass varied little among treatment diets. This could indicate a lack of plasticity in these key fitness parameters.

In sum, from these two bioassay experiments, it appears as if prickly poppy defenses vary within plants and among species. Overall, the negative effects of poppy leaves and extracts on herbivore performance were weaker than expected. Because we inspected multiple fitness parameters in both bioassays (Kariyat \& Portman 2016), we have considerable confidence in the conclusion that prickly poppies have weak effects on the performance of these two generalist herbivores. While recent reviews emphasize the resistance of generalist herbivores to plant secondary compounds in their hostplants (Smilanich et al. 2016), it is nonetheless striking that both species of noctuids examined here suffered only weak reductions in fitness when fed diets that included prickly poppy leaves or extracts. It may be that these non-native noctuid caterpillars are generally very tolerant to secondary compounds and tough leaves, consistent with their ability to consume a vast diversity of host plants. Further studies with native insect herbivores are needed to determine whether the responses of these non-native noctuid caterpillars are not typical. In addition, it has been suggested that prickles deter vertebrate herbivores more than insect herbivores (Grubb 1992, Briand \& Soros 2001), highlighting the need for additional research on other guilds of herbivores. Alternatively, prickles, latex, and sclerophylly may be more important for other ecophysiological roles than for defense. Trichomes, for example, are well known to play an ecophysiological role, reflecting light and reducing photoinhibition (Jordan et al. 2005, Liakopoulos et al. 2006). Prickles are anatomically very similar to trichomes (Bell \& Bryan 2008), and previous work has demonstrated that prickles can be induced to greater densities under high light in the Hawaiian prickly poppy, Argemone glauca (Barton 2014). Future research examining herbivory by other guilds and the function of prickles, latex, and sclerophylly under abiotic stress would provide new insights into this interesting group of plants. 


\section{Acknowledgments}

The authors thank Will Haines for collecting the moths and for rearing advice; Kari Bogner and Jessica Quayle for laboratory assistance; Karina Boege, Nikisha Patel, Weston Testo, Michael Sundue, Dave Barrington, Susan Fawcett, and three anonymous reviewers for helpful reviews of the manuscript. Funding was provided by the NSF CNIC program (OISE-1427127) and the College of Natural Sciences, University of Hawaii at Manoa to KEB.

\section{Literature Cited}

Agrawal AA, Fishbein M. 2006. Plant defense syndromes. Ecology 87: 132-149. DOI: 10.1890/00129658(2006)87[132:PDS]2.0.CO;2

Agrawal AA, Fishbein M, Jetter R, Salminen JP, Goldstein JB, Freitag AE, Sparks JP. 2009. Phylogenetic ecology of leaf surface traits in the milkweeds (Asclepias spp.): chemistry, ecophysiology, and insect behavior. New Phytologist 183: 848-867. DOI: 10.1111/j.1469-8137.2009.02897.x

Agrawal AA, Konno K. 2009. Latex: A Model for Understanding Mechanisms, Ecology, and Evolution of Plant Defense Against Herbivory. Annual Review of Ecology Evolution and Systematics 40: 311-331. DOI: 10.1146/annurev.ecolsys.110308.120307

Ali JG, Agrawal AA. 2012. Specialist versus generalist insect herbivores and plant defense. Trends in Plant Science 17: 293-302. DOI: 10.1016/j.tplants.2012.02.006

Ansari KM, Chauhan LKS, Dhawan A, Khanna SK, Das M. 2004. Unequivocal evidence of genotoxic potential of argemone oil in mice. International Journal of Cancer 112: 890-895. DOI: 10.1002/ijc.20319

Barton KE. 2014. Prickles, latex and tolerance in the endemic Hawaiian prickly poppy (Argemone glauca): Variation between populations, across ontogeny and due to phenotypic plasticity. Oecologia 174: 12731281. DOI: $10.1007 / \mathrm{s} 00442-013-2836-\mathrm{z}$

Bell AD, Bryan A. 2008. Plant Form: An Illustrated Guide to Flowering Plant Morphology. Timber Press, London.

Bennett RN, Wallsgrove RM. 1994. Secondary metabolites in plant defense - mechanisms. New Phytologist 127: 617-633. DOI: 10.1111/j.1469-8137.1994.tb02968.x

Benrey B, Denno RF. 1997. The slow-growth-high-mortality hypothesis: A test using the cabbage butterfly. Ecology 78: 987-999. DOI: 10.2307/2265852

Brahmachari GD, Gorai D, Roy R. 2013. Argemone mexicana: chemical and pharmacological aspects. Brazilian Journal of Pharmacognosy 23: 559-575. DOI: 10.1590/S0102-695X2013005000021

Briand CH, Soros CL. 2001. Spatial variation of prickle abundance on leaves of the devil's walking stick (Aralia spinosa; Araliaceae) during the trunk-building phase. Journal of the Torrey Botanical Society 128: $219-225$. DOI: $10.2307 / 3088713$

Capasso A, Piacente S, Pizza C, De Tommasi N, Jativa C, Sorrentino L. 1997. Isoquinoline alkaloids from Argemone mexicana reduce morphine withdrawal in Guinea Pig isolated ileum. Planta Medica 63: 326328. DOI: $10.1055 / \mathrm{s}-2006-957693$

Chang YC, Chang FR, Khalil AT, Hsieh PW, Wu YC. 2003. Cytotoxic benzophenanthridine and benzylisoquinoline alkaloids from Argemone mexicana. Zeitschrift Fur Naturforschung C 58: 521-526.

Clancy KM, Price PW. 1987. Rapid herbivore growth enhances enemy attack: sublethal plant defences remain a paradox. Ecology 68: 736-738. DOI: 10.2307/1938479

Ehrlich PR, Raven PH. 1964. Butterflies and plants: a study in coevolution. Evolution 18: 586-608. DOI: $10.2307 / 2406212$

Eigenbrode S, Espelie KE. 1995. Effects of plant epicuticular lipids on insect herbivores. Annual Review of Entomology 40: 171-194. DOI: 10.1146/annurev.ento.40.1.171

Fricke EC, Haak DC, Levey DJ, Tewksbury JJ. 2016. Gut passage and secondary metabolites alter the source of post-dispersal predation for bird-dispersed chili seeds. Oecologia 181: 905-910. DOI: 10.1007/s00442-016-3612-7

Fritz RS, Simms EL, eds. 1992. Plant Resistance to Herbivores and Pathogens. Chicago: The University of Chicago Press. ISBN 9780226265537

Givnish TJ, Sytsma KJ, Smith JF, Hahn WJ. 1994. Thorn-like prickles and heterophylly in Cyanea - adaptations to extinct avian browsers on Hawai'i. Proceedings of the National Academy of Sciences 91 : 2810-2814. DOI: 10.1073/pnas.91.7.2810

Goeden RD, Ricker DW. 1985. Prickly poppies, Argemone corymbosa and Argemone munita, in Southern California - native weeds attacked by few insects. Annals of the Entomological Society of America 78: 214-216. DOI: https://doi.org/10.1093/aesa/78.2.214

Grubb PJ. 1992. A positive distrust in simplicity - lessons from plant defenses and from competition among plants and among animals. Journal of Ecology 80: 585-610. DOI: 10.2307/2260852 
Guizar-Gonzalez C, Trujillo-Villanueva K, Monforte-Gonzalez M, Vazquez-Flota F. 2012. Sanguinarine and dihydrosanguinarine accumulation in Argemone mexicana (L) cell suspension cultures exposed to yeast extract. Journal of the Mexican Chemical Society 56: 19-22.

Hanley ME, Lamont BB, Fairbanks MM, Rafferty CM. 2007. Plant structural traits and their role in anti-herbivore defence. Perspectives in Plant Ecology, Evolution and Systematics 8: 157-178. DOI: 10.1016/j.ppees.2007.01.001

Hoan R, Ormond R, Barton KE. 2014. Prickly poppies can get pricklier: ontogenetic patterns in the induction of physical defense traits. PLOS ONE 9: E96796. DOI: 10.1371/journal.pone.0096796

Honek A. 1993. Intraspecific variation in body size and fecundity in insects - a general relationship. Oikos 66: 483-492. DOI: $10.2307 / 3544943$

Huang TF, Jander G, de Vos M. 2011. Non-protein amino acids in plant defense against insect herbivores: Representative cases and opportunities for further functional analysis. Phytochemistry 72: 1531-1537. DOI: 10.1016/j.phytochem.2011.03.019

James HF, Burney DA. 1997. The diet and ecology of Hawaii's extinct flightless waterfowl: evidence from coprolites. Biological Journal of the Linnean Society 62: 279-297. DOI: 10.1111/j.1095-8312.1997. tb01627.x

Jordan GJ, Dillon RA, Weston PH. 2005. Solar radiation as a factor in the evolution of scleromorphic leaf anatomy in Proteaceae. American Journal of Botany 92: 789-796. DOI: 10.3732/ajb.92.5.789

Karban R, Agrawal AA. 2002. Herbivore offense. Annual Review of Ecology and Systematics 33: 641664. DOI: 10.1146/annurev.ecolsys.33.010802.150443

Kariyat RR, Portman SL. 2016. Plant-herbivore interactions: Thinking beyond larval growth and mortality. American Journal of Botany 103: 789-791. DOI: 10.3732/ajb.1600066

Konstantopoulou E, Kapotis G, Salachas G, Petropoulos SA, Karapanos IC, Passam HC. 2010. Nutritional quality of greenhouse lettuce at harvest and after storage in relation to $\mathrm{N}$ application and cultivation season. Scientia Horticulturae 125: 93-94. DOI: 10.1016/j.scienta.2010.03.003

Koricheva J, Nykanen H, Gianoli E. 2004. Meta-analysis of trade-offs among plant antiherbivore defenses: Are plants jacks-of-all-trades, masters of all? American Naturalist 163: E64-E75. DOI: $10.1086 / 382601$

Liakopoulos G, Nikolopoulos D, Klouvatou A, Vekkos KA, Manetas Y, Karabourniotis G. 2006. The photoprotective role of epidermal anthocyanins and surface pubescence in young leaves of grapevine (Vitis vinifera). Annals of Botany 98: 257-265. DOI: 10.1093/aob/mc1097

Liu YQ, Fu XW, Mao LM, Xing ZL, Wu KM. 2016. Host Plants Identification for Adult Agrotis ipsilon, a Long-Distance Migratory Insect. International Journal of Molecular Sciences 17. DOI: 10.3390/ ijms 17060851

Luther GC, Valenzuela HR, Defrank J. 1996. Impact of cruciferous trap crops on lepidopteran pests of cabbage in Hawaii. Environmental Entomology 25: 39-47. DOI: 0046-225X196100390047\$02.00/O

McCall AC, Fordyce JA. 2010. Can optimal defence theory be used to predict the distribution of plant chemical defences? Journal of Ecology 98: 985-992. DOI: 10.1111/j.1365-2745.2010.01693.x

McKey D. 1979. The distribution of secondary compounds within plants. In: Rosenthal GA, Janzen DH, eds. Herbivores: Their interactions with secondary plant metabolites. New York: Academic Press. 55-133. ISBN 9780125971805

Meléndez PA, Capriles VA. 2002. Molluscicidal activity of plants from Puerto Rico. Annals of Tropical Medicine and Parasitology 96: 209-218. DOI: 10.1179/000349802125000600

Oliveira AFM, Meirelles ST, Salatino A. 2003. Epicuticular waxes from caatinga and cerrado species and their efficiency against water loss. Anais Da Academia Brasileira De Ciencias 75: 431-439. DOI: 10.1590/S0001-37652003000400003

Osho A, Adetunji T. 2010. Antimicrobial activity of the essential oil of Argemone mexicana Linn. Journal of Medicinal Plants Research 4: 19-22. DOI: 10.5897/JMPR09.204

Potter DA, Kimmerer TW. 1988. Do holly leaf spines really deter herbivory? Oecologia 75: 216-221. DOI: 10.1007/BF00378601

Reyes FD, Peña CJ, Canales M, Jiménez M, Meráz S, Hernandez T. 2011. Antimicrobial activity of Argemone ochroleuca Sweet (Chicalote). Boletin Latinoamericano Y Del Caribe De Plantas Medicinales $Y$ Aromaticas 10: 139-146.

Saeki Y, Crowley P. 2012. Temperature effects during development on a polyembryonic parasitoid and its host. Journal of Thermal Biology 37: 602-607. DOI: 10.1016/j.jtherbio.2012.07.008

Sakthivadivel M, Thilagavathy D. 2003. Larvicidal and chemosterilant activity of the acetone fraction of petroleum ether extract from Argemone mexicana L. seed. Bioresource Technology 89: 213-216. DOI: 10.1016/S0960-8524(03)00038-5

Scholz I, Buckins M, Dolge L, Erlinghagen T, Weth A, Hischen F, Mayer J, Hoffmann S, Riederer M, Riedel M, Baumgartner W. 2010. Slippery surfaces of pitcher plants: Nepenthes wax crystals minimize 
insect attachment via microscopic surface roughness. Journal of Experimental Biology 213: 1115-1125. DOI: $10.1242 /$ jeb.035618

Schreiber L, Riederer M. 1996. Determination of diffusion coefficients of octadecanoic acid in isolated cuticular waxes and their relationship to cuticular water permeabilities. Plant Cell and Environment 19: 1075-1082. DOI: 10.1111/j.1365-3040.1996.tb00214.x

Schwarzbach AE, Kadereit JW. 1999. Phylogeny of prickly poppies, Argemone (Papaveraceae), and the evolution of morphological and alkaloid characters based on ITS nrDNA sequence variation. Plant Systematics and Evolution 218: 257-279. DOI: 10.1007/BF01089231

Shaukat SS, Siddiqui IA, Khan GH, Zaki MJ. 2002. Nematicidal and allelopathic potential of Argemone mexicana, a tropical weed - Allelopathic and nematicidal potential of Argemone mexicana. Plant and Soil 245: 239-247. DOI: 10.1023/A:1020476024966

Singer MS, Farkas TE, Skorik CM, Mooney KA. 2012. Tritrophic interactions at a community level: Effects of host plant species quality on bird predation of caterpillars. American Naturalist 179: 363-374. DOI: $10.1086 / 664080$

Singh S, Singh TD, Singh VP, Pandey VB. 2010. A new benzylisoquinoline alkaloid from Argemone mexicana. Natural Product Research 24: 63-67. DOI: 10.1080/14786410902800723

Smilanich AM, Fincher RM, Dyer LA. 2016. Does plant apparency matter? Thirty years of data provide limited support but reveal clear patterns of the effects of plant chemistry on herbivores. New Phytologist 210: 1044-1057. DOI: $10.1111 /$ nph. 13875

Verma SK, Dev G, Tyagi AK, Goomber S, Jain GV. 2001. Argemone mexicana poisoning: autopsy findings of two cases. Forensic Science International 115: 135-141. DOI: 10.1016/S0379-0738(00)003224

Wagner WL, Herbst DR, Sohmer SH. 1999. Manual of the Flowering Plants of Hawai'i. Honolulu: University of Hawai'i Press, Bishop Museum Press.

Xu CM, Zhang ZQ, Cui KD, Zhao YH, Han JK, Liu F, Mu W. 2016. Effects of sublethal concentrations of cyantraniliprole on the development, fecundity and nutritional physiology of the black cutworm Agrotis ipsilon (Lepidoptera: Noctuidae). PLOS ONE 11. DOI: 10.1371/journal.pone.0156555 